\title{
Latin-American perceptions on definitions and arguments about crossmedia and transmedia in advertising
}

\author{
Pedro Hellín-Ortuño; Eneus Trindade; Javier García-López
}

How to cite this article:

Hellín-Ortuño, Pedro; Trindade, Eneus; García-López, Javier (2019). "Latin-American perceptions on definitions and arguments about crossmedia and transmedia in advertising". El profesional de la información, v. 28, n. 4, e280408.

https://doi.org/10.3145/epi.2019.jul.08

Manuscript received on $10^{\text {th }}$ Nov 2018 Accepted on $2^{\text {nd }}$ Apr 2019

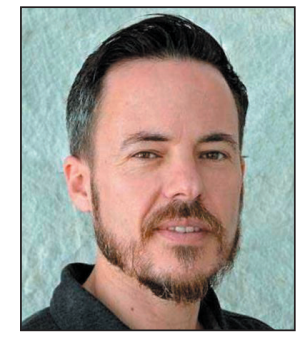

Pedro Hellín-Ortuño

https://orcid.org/0000-0002-1331-5103

Universidad de Murcia

Facultad de Comunicación y

Documentación

Campus Universitario de Espinardo, 8.

30100 Murcia, Spain

phellin@um.es

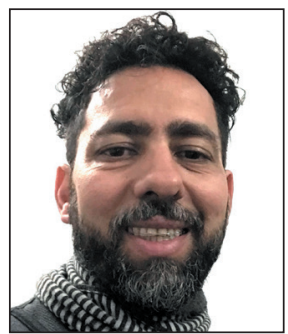

Eneus Trindade

https://orcid.org/000-0001-8231-4027

University of São Paulo

Av. Prof. Lúcio Martins Rodrigues, 443

Butantã, São Paulo - SP, 05508-020 Brasil

eneustrindade@usp.br

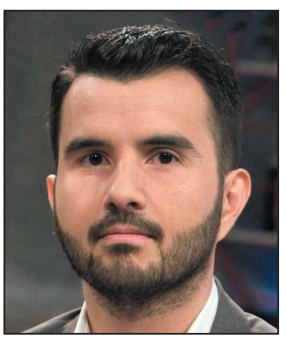

\author{
Javier García-López $₫$ \\ https://orcid.org/0000-0002-7306-4289 \\ Universidad de Murcia \\ Facultad de Comunicación y \\ Documentación \\ Campus Universitario de Espinardo, 8. \\ 30100 Murcia, Spain \\ javier.garcialopez@um.es
}

\begin{abstract}
Digital society has caused changes in the conventional forms of advertising. The values and interactive processes associated lead commercial brands to adapt to new situations. This paper reflects on crossmedia and transmedia storytelling concepts and their use in the Latin American context. There has been a transformation built on a hypermodern society, influenced by sociotechnological devices. The main objectives of this work are to define and categorize the new advertising formats arising from this context, as well as to identify the new conceptual manifestations. Through a conceptual revision, the text shows that the traditional forms of strategic advertising planning are changing, determined by conceptual and media hyperrelation. Now there is a sense of growing consumer power, who is also an active consumer of social media and advertising. In the current Latin American context, the consumer becomes a necessary collaborator in the process of producing meaning.
\end{abstract}

\section{Keywords}

Crossmedia; Transmedia; Storytelling; Brands; Concepts; Definitions; Advertising; Interactivity; Values; Digital trends; Consumers; Prosumers; Categories; Social media; Latin America. 


\section{Introduction}

This work aims to define and categorise new advertising formats such as publications (Casaqui, 2011), which arose as a result of the transformation promoted by the sociotechnological intervention of media devices on hypermodern or postmodern society (Fausto-Neto, 2010) with their contemporary social values.

Such values and interactive processes characterise new or alternative environments for the "movement of trademarks" (planned media and format rotation of brand advertising) in the context of the phenomena referred to as transmedia or crossmedia: generators of meaning for the consumer society.

The text focuses on the unique identifying aspects of these conceptual manifestations, calling into question possible similarities and dissimilarities between the concepts of crossmedia and transmedia storytelling for communicational reflection within the Latin American context.

It is necessary to clarify that the first part of the discussion refers to brand management in the context of the consumer society today. That is, how to think about the "movement of brands" in the current consumption context. For that purpose, authors such as Lipovetsky (2007) -and his concepts of hypermodernity and excessive consumption- are used, among others, and are associated with the ideas of Hellín-Ortuño (2007) on advertising and post-modern values.

Beginning from the premises of this discussion on communicational management of brands, a discussion is initiated on the Brazilian perspective of media development and utilisation given by Couldry and Hepp (2013), on the Brazilian perceptions of the term given in Braga (2006b) and the related concepts of publication (Casaqui, 2011) and "circulation/ movement" (Fausto-Neto, 2010), as theoretical dimensions necessary for the understanding of new forms of the communicative advertising on the internet.

Then, final thoughts are woven about the relevance of the creation and operation of procedures for observing network communication. From these thoughts a conclusion is drawn, commenting on the implications of these phenomena to communicative thinking. We discuss the problematic nomenclature that has been used to explain such so-called phenomena storytelling transmedia and crossmedia, especially seeking ways to delineate the horizons of this terminology and its uses in advertising communication in the Latin American context.

\section{Materials and methods}

A literature review has been used in order to identify the most relevant research on crossmedia and transmedia concepts and their relationship with advertising and the current context of consumption, in order to conduct the study, following the recommendations of Codina (2018, p. 87). It has been necessary to define and categorize new nomenclatures and advertising formats arising from this context.

Likewise, the new conceptual manifestations associated with crossmedia and transmedia concepts within the advertising framework are identified. For the development of nomenclature questions, it is considered that there is a need for an initial literature review found in the two leading advertising research journals (Journal of Advertising Research and International Journal of Advertising), which allowed themselves to anticipate that this is a factual ongoing process and that the traits that define transmediatization and crossmedia are still not fully constructed. Our search began by using the terms: "transmedia", "advertainment" and "crossmedia". No articles were identified with the term "transmedia", but the term "crossmedia" has been found in 733 articles, and the term "advertainment" has been found in 211 articles. All identified texts were published in the last two decades.

Then, in the proposed sense, a critical reflection is carried out, with special attention to future lines in the development of discourses and advertising formats in the digital social environment.

\section{Results}

\subsection{Brand management in the consumer society}

These days one can see a new configuration in the socio-cultural context called 'late modernity' by some (Giddens, 2002), liquid modernity by others (Bauman, 2001), or hypermodernity (Lipovetsky, 2007). This concept has been chosen for this article to work with the paradoxes of the values and meanings which constitute current consumerism, and is therefore the determinant of brand management in the contemporary world.

The world of hypermodernity and excess consumption, described by Lipovetsky (2007), is a world full of paradoxes, which reflect the current evolution of capitalism and which are manifested by the search for a new "-ism", materialized in hedonistic consumption in unconnected areas of material life, resulting continuously in desires that motivate their realization by means of consumption, with the constant imminence of frustration that can generate continuous searches ad infinitum.

That, according to the author, is converting interested parties into the "civilization of desire", and authors like Semprini (2006) consider that current branding is changing to adapt to this dynamic context. Among the main challenges facing brands are such questions as: How can loyalty attract new consumers in an era marked by the pursuit of hedonistic 
consumer experiences? How to design brand communication strategies in formats and creative ways so as to reach consumers in virtual locations of the digital media and in the physical world?

Hellín-Ortuño (2007) notes that this setting also affects advertising which seeks to understand postmodern values as elements that convert to social values, which incorporate themselves into advertisements and that in turn in media circulation, they become the brand values and consequently, also those of their consumers. Such advertisements have functioned as devices and supports for recording cultural changes, because, as Caro-Almala (2007, p. 84) has explained

"advertising is the core of the social imaginary that now extends worldwide as a substantial component of capitalist globalization".

This change of corporate values creates the need for new forms of corporate socialization, generating new issues for communication and semiotics research, because of new communication formats, new encoding devices, interaction and brand message "movement" (again, the planned rotation of formats and media for brand publicity).

It is no coincidence that Kotler, Kartajaya and Setiawan (2011) to think about ways to make Marketing 3.0, take into consideration the new communications environment (which includes brand management in a complex and dynamic context), in which the public ought not to be seen as fixed targets and in which brands must be in permanent transformation, searching for new points of contact, including devices connected to the communications network.
The change of corporate values creates the need for new forms of corporate socialization, generating new issues for communication and semiotics research, because of new communication formats, new encoding devices, interaction and brand message "movement"

All this points to the effective demise of the linear communication scheme based on the transmitter-receiver relationship, to which is added the aspect that communications transfer meanings to objects by means of representations and media forms of the consumer advertising system, as had already been dealt with by Baudrillard (1969). Furthermore, today such a mechanism is best articulated by McCracken (2003) because nowadays such processes/rituals lend themselves more than ever to begin with the use of new media devices which put different applications to use and which create new interactive forms so as to establish consumer relations with repercussions on the lives of their users-consumers.

In this way, the idea of media coverage can now be explained as a theoretical linkage point between the contexts of brand publicity performance and that of advertising in the communications field.

\subsection{Publication and circulation in mediatization (media coverage processes)}

In an attempt to outline this new communicative context of brands, it is realized that all areas of daily life are also permeated by the presence of the media (Couldry; Hepp, 2013, pp. 191-192). The dated impact of media on society is not being dealt with here, but rather the idea of a strong regulatory presence and integrated media devices, which constitute a logical and interactive construction that can establish values and references that serve the crystallization, or even logical and ephemeral, values for alternative or new practices of cultural reference. That is what is called media coverage.

In the countries here dealt with, Spain and Brazil, it is believed from the studies of Benavides-Delgado (2005) and Braga (2006b), that the media coverage process is still in the throes of development and, in some ways, is linked to the idea of forthcoming understandings about media literacy, as illustrated in the work of Livingstone (2011). That work takes into account the study of the interactive logic imposed by new socio-technological media processes and their consequent, but as yet unconsolidated, discursive communication as being an example of writing that is a practical cultural benchmark for reference to knowledge practices to the detriment of other forms of interaction that could also be considered as legitimate for access to knowledge.

In such a process of virtual relations there emerges a new interactive logic that subverts the linearity of communication and facilitates an awareness of the media circulatory diffusion process of brand advertising, as explained by Fausto-Neto (2010); causing to emerge, contrary to the practices of interaction, traces of this movement, especially in the case of interest of this work, with regard to promotional formats of the messages in online social networks.

In reviewing the history of the media, it is noticeable that the receiver, by residual traces of this communication movement, becomes prominent, especially by reason of his major role, as a result of the new socio-technological processes that enable this kind of performance.

To the previous observation one can add the understanding that the communication process does not end with the receiver, but rather acquires new dimensions of meaning, and finds other nodes in the process of dissemination of information that are no longer under the control of the traditional media production centres.
In the process of virtual relations emerges a new interactive logic that subverts the linearity of communication and facilitates an awareness of the media circulatory diffusion process of brand advertising 
The status of these issues raises others that put at risk the traditional ways of brand communication and advertising, opening the door to what some authors, such as Casaqui (2011), call publicity.

This concept, in the context of media coverage, is applied to try to describe the proven forms of purposeful rotational alternation for promoting brands using media devices that are other formats outside of the conventional advertising family and with a more active involvement of the subject in the communicational process receptor.

The publicitation would then be an expansion of, or an elasticisation of the traditional advertising concept, which is much more cost effective and is compatible with the idea of the semiotic system of publicity given in (Hellín-Ortuño, 2007, p. 28) or of simply treating this publicitation as an advertising system (Rocha, 2006, pp. 12-13). This is because of the notion of a system to harbour all forms of communicative expression of brands, such as points of contact which generate sensory bonds between the receivers-consumers-users-developers-prosumers (electronic equipment users) in the current consumer culture.

This complex dimension of objective terminology for the question of reception and absorption into cultures, in addition to instigating questions about an ethical perspective relative to the status of such terms within the field of communication, is exemplified in the reflections used in the studies of reception in Latin America by Checa-Montúfar (2011), which deal with receptiveness through Intel's studies of media consumption.

In addition to previous discussions given in this work, there are others that put the focus onto the crossmedia reflections proposed by Jenkins (2008).

This phenomenon of media consumption, handled by the author as transmedia storytelling, configures itself, roughly speaking, through creative ways of telling the stories. That is, the phenomenon, in the case of the interest in the manifestations of the advertising system, refers to the movement (as previously defined: the planned media and format rotation of brand advertising) of interlocking narratives. These are not necessarily interdependent or complementary to each other in the multi-platform communication use of film productions, of televised fiction or of brand publicity strategies to promote experiments in (1) mediation and media involvement, (2) in the consumption of consumer goods and services and (3) other such products of the current culture.

These experiments, particularly those brought to fruition in social networks or in digital media in the case of promotional communications, allow the monitoring of the circulation processes of media and format rotation for brand advertising. Furthermore, they provide the suggestion of the study of communication models that include the observation and monitoring of this multi-platform nature, as a way of understanding the logics imposed on the interaction with the media and also to understand the points of contact between consumers and the brands in usage and consumption situations. Because this relates to the marketing study of Di-Nallo (1999), and in particular to the points of contact with the consumer, it corresponds to the great challenge of the contemporary marketing area, in which audiences are dynamic and the focus of understanding is on consumption through an understanding of situations in which consumption occurs.

\subsection{The importance of network monitoring}

One of the possibilities of understanding these new phenomena of establishing the professional marketing practices and the need for this observation by academics, is the monitoring of network environments as a way to recovering information about the media circulatory diffusion process which is neither unidirectional nor classically interactive.

This aspect involves two procedures: the first involves reflections on classical forms of observation and their adaptations to the task, with definitions and boundaries appropriate to digital environments; and secondly, the use of technological tools (software), for information retrieval, and the grouping and analysis of the data which is recovered for research within the media ambience.

For the first of the above-mentioned procedures, works of Braga (2006a) and Ribeiro \& Bairon (2007) are featured. These, beginning from an anthropological base, proceed to think about sensitive ways of understanding the "netnographies" of cultures. These authors are examples of many others, pointing to the importance of perceiving ethnographic studies in other written dimensions or cultural registration forms, as in the case of digital social networking environments. In this sense, what are the criteria for making these comments? What are the conditions under which these records can be valid for an investigation?

In digital life, immersion in social networks promotes understanding of the points of contact of brands with consumers, revealed through indications of directional flows, whose analysis can trace the theoretical meaning of directional links established in their interactive processes with their logical ones, thus allowing both an understanding of how to think about creative strategies in brand communication or publicity, as also to incite one to perceive the power which arises in the receiver-fan-consumer dimension, and maybe, in that of the producer-consumer-prosumer, as Henry Jenkins would say.

Furthermore, for the market, these strategies are the possibilities of innovation which these days challenge traditional models of advertising, demonstrating the search for brand activation programmes through undercover activities that add, to the collection of transmedia narratives, the idea of commercial transmedia narratives. These, in turn, are called crossmedia. Such a phenomenon is presented through a wide variety of solutions that can be mapped and which compel 
the proposal of alternative ways of thinking about brand communicational management and its theorisation in the field of media studies.

Crossmedia and transmedia storytelling are concepts considered by many authors as synonymous terms, as shall be seen further on. However, the origins of the two terms are distinct, although they do refer to similar or related phenomena. Such an observation provoked the comprehension of the existence of a conceptual distinction, as regards the phenomena of transmedia storytelling and cross-media in Latin-American ambiences relative to the Anglo-Saxon scientific context of media studies. Hence, there is an endeavour made here to initiate an already unfolding embryonic discussion.

In this sense, theoretical studies about transmediatized communications in Spain and Brazil are highlighted. The examples of Scolari (2009), Lacalle (2010), Amorós-Pons \& Comesaña-Comesaña (2016) and Garrido-Pintado \& Estupiñán-Estupiñán (2016) in Spain and Lopes $(2009 ; 2011 ; 2013)$ in Brazil explore the realms of transmediatization in advertising, in film, in television fiction, and make valuable contributions to building semiotic dimensions of cultural interpretations of consumption. These latter resulted from the cross fertilisation of these complementary narratives in the lives of their receivers. These conformed perfectly with the possibilities of media consumption about brand narratives and with their dissemination strategies.

In addition, there is the second of the above-mentioned procedures with respect to the forms of search and retrieval of information which will compose these interactive environments. These days research cannot be done without research tools to locate the desired content. The most traditional of these is the soundtrack for "tag", terms which identify issues or information to be (1) quantified, (2) qualitatively grouped, and (3) identified as being relevant or not. This is the logic of semantization which Levy (2011) deals with, incorporating the algorithmic logic into the production system of a new advertisement.

With this perspective of understanding it is possible to start an analysis of content and/or a discourse analysis. This would be in addition to the visualization of these interactive spaces which allow for observation of the ways in which these digital environments are used, as well as the possibility of the appropriation by the observed subjects of their own media uses and their habits within the perspective of a media coverage of their own lives.

For this, the use of software is essential. It should allow for capture, organization, and data logging, according to the needs of research on these issues. These softwares can be created and adjusted to specific brand case studies, beginning from concepts which make possible the identification and grouping of formats for the ascertainment, routings and routines which, generate a general understanding about the actions of promotion as a communication strategy in other stages of the interaction process.

In this work, examples have not been introduced of advertising formats or actions that arise within digital networks and that are often associated with transmedia strategies for brand promotion. That is what is called 'publication in the circulation context' and which configures the mediatization process as something taken for granted, as having been created as an international practice that may, or may not, become cultural reference practices, may, or may not, be termed as practices of culturally based reference. But these are presented in the context of formative social media processes. Still, it is desirable to discuss here the terminological question of transmediatization and crossmedia as a point of departure to the understanding of such research in the area.

\subsection{Nomenclature questions. Transmedia vs. crossmedia in the Latin-American context}

What can be concluded from this preliminary process is that it still continues with an in-depth look at the issue. This issue is essentially that there is an epistemological difference in the treatment of directional movement (as previously defined: the order of release of formats and media of brand advertising) and their social network publication between Latin-Americans and Anglo-Americans.

Although Ibrus and Scolari (2012) in their book "Crossmedia innovations" treated both such phenomena as synonyms, some differences were found between the terms and these have set out in the following table.

In the Latin American context, the theoretical work of circulation in social networks is considered to be mostly based on the concept of transmedia. The crossmedia concept is only used in the context of the market and in the promotion of products, services and cultural goods. Crossmedia takes on characterisations of deterministic traits to generate results, and characteristics of anticipated effects, for example, in the traditional linear communication market, without reaching the complexity of transmedia storytelling narratives.

Based on the work of Lopes (2011, pp. 23-24) an historic bailout was found similar to the one here in which there was an attempt to trace as a differential between the terms cross-media and transmedia storytelling that reinforce collocations. For the Lopes group, the term "transmedia", before Jenkins (2008) spread it into the scientific and university world, and it was no longer a novelty for the market, since its application is still found 70 years later in the saga of Star wars. In the 1990's, other researchers systematized knowledge with the use of the term, as did Marsha Kinder, dealing with commercial systems transmedia, thereby opening avenues for thoughts proposed by Jenkins. 
Table 1. Differences in terminology: Transmedia storytelling and crossmedia

\begin{tabular}{|c|c|}
\hline Transmedia storytelling & Crossmedia \\
\hline $\begin{array}{l}\text { Context more of the Europe, United States and Latin America fa- } \\
\text { cing the media fictions }\end{array}$ & $\begin{array}{l}\text { Global advertising market context. Widely used term in the academic world } \\
\text { of Anglo-Saxon advertising communication }\end{array}$ \\
\hline $\begin{array}{l}\text { An expanded multi-platform universe with extensive possibilities } \\
\text { and without time limits. }\end{array}$ & $\begin{array}{l}\text { An expanded multi-platform universe conditioned to a strategy of making a } \\
\text { brand have expanded universe, for a given time. }\end{array}$ \\
\hline Serialised fiction of cinema. & Advertising and branding. \\
\hline Involvement and participation & Involvement but more limited participation \\
\hline Autonomy. Possibility of richer interactive schemes & $\begin{array}{l}\text { Relative autonomy. Programmed, but often limited by interaction scheme } \\
\text { programming. }\end{array}$ \\
\hline Co-authorship and collaboration; empowered by consumer-user. & $\begin{array}{l}\text { Minimal co-authorship, but with collaboration. Consumer-user with illusion } \\
\text { of empowerment. }\end{array}$ \\
\hline $\begin{array}{l}\text { Theoretical possibilities for communication and new education } \\
\text { with skills in media literacy. }\end{array}$ & $\begin{array}{l}\text { Market power and language prevail, with theoretical views transiting betwe- } \\
\text { en the linear communication model and the new interactional possibilities. }\end{array}$ \\
\hline Production mode beginning from, and within, the media. & A functional manner of using the media. \\
\hline $\begin{array}{l}\text { Convergence shapes narrative production which remains open to } \\
\text { chance; open too to developments. }\end{array}$ & $\begin{array}{l}\text { Convergence shapes narrative production planned with a view to results. } \\
\text { Only chance welcomes positive reactions. Negatives lead to the abandon- } \\
\text { ment of the process, although they can generate independent narratives of } \\
\text { the desire for brand management. }\end{array}$ \\
\hline
\end{tabular}

Already the term Crossmedia is rather historical. Its use is more...

[...] widespread within advertising and marketing to describe campaign strategies which opt for the reiteration of the same content in different media, expanding its public audience and reinforcing the appeal in advertising.

According to Davidson (2010), digital media have transformed the nature of this articulation among different platforms, allowing for integration between media to explore the consumer's ability. For him, the expression "crossmedia communication" may these days designate the same kind of experience described by Henry Jenkins "transmedia".

It is preferred, however, to preserve the two denominations with their different perspectives, reserving the term crossmedia to designate only the integrated use of various media and the term transmedia coverage to describe certain content development strategies from precisely this use of different media. The first (crossmedia) refers to a particular way of using the media and the second (transmedia coverage) for a particular mode of production of contents from the convergence of media (Lopes, 2011, p. 23-24).

Still, through the work of Lopes (2011, p. 31), it is understood that transmedia storytelling is just one of the forms of the transmedia manifestation because there will not always be an opening narrative included in transmedia-coverage. At the same time, not all transmedia narrative is born for commercial purposes.

In his review on studies of Brazilian soap opera, (Lopes, 2013) organised a book with multiple authors that dealt with transmedia promotion and actions and with crossmedia in the soap operas of TV Globo. The results of Lopes's research point to the fact that the promotability of the soap opera cultural product fits neatly into the logic of crossmedia.

In the light of this exposure will the issues become one of whether there is indeed transmediatisation in advertising? Since the attempts so far point to an even larger control on the part of those who transmit, how are the roles of producer, transmitter and receiver to be separated in transmediatisation? Are there different categories or are they all mixes? For example, are they different; the emitter's interaction attempts and the receptor's interactions, and likewise the results of those interactions of this receiver, the spontaneous productions of consumers?

Is there a favourable scenario for that in the future, or is the universe of advertising to be expanded transmediately? Or will advertising restrict the idea of crossmedia instituted by the market?

Far from having an answer to these questions, it is preferable to share questions, to reflect on the issue and on the sequence of its occurrences, aware that a conclusive outcome on the issue under discussion is a long way off.

But another point that deserves consideration is one that points back to matter that the English speaking literature does not appear to question the nomenclature of advertisement formats originating from the market, and uses words and phrases that are currently-fashionable jargon.

For this reason and because advertising jargon is globalized, differences have not been identified here between the types of names and formats in English speaking and Latin-American contexts.

Even so, although such an affirmation is premature, and also this is not the intention of this research, and there is convincing evidence that the Latin-American context appears to be more critical of the nomenclatures that arise in professional advertising jargon. The English speaking are more concerned with analysing communication strategies within the market perspective of the effects and impacts of messages, and are linked to crossmedia actions or perhaps isolated 
narratives. They therefore trace the contextual peculiarities of specific markets (1) where they interact and the fact that they are (2) circulating on the internet, and finally, relative to (3) their dependence on their classification as strategic tools for "advertainment" (advertising/entertainment).

This means that, these days, a set of examples have been created that can be composed of expressions that act on digital networks and also, may or may not, consist of multi-platforms with narratives which complement one another and which demarcate the limits of publication strategies of brands in their processes of circulation or distribution. In addition to this, it is appropriate to emphasise that these strategies function as applications of product placement, i.e. complementary placement of products/brands with usage demonstrations, visual stimuli, comments on the product/ brand, even if that may contribute little for the purpose of clarifying the complexity of the phenomena being dealt with.

The formats in advertainment and crossmedia, may be Web advertising campaigns, viral advertising, lip dub (the synchronisation of lip movements and audio dubbing to make a music video), animation, hidden camera, street advertisements, social networks (with use of visual and audiovisual resources and online chat systems), and augmented reality. All these are among ad-

A set of examples have been created that can be composed of expressions that act on digital networks and also, may or may not, consist of multi-platforms with narratives which complement one another

ditional possibilities whose settings can be framed in publication logistics already presented, in which the feelings of consumer-receiver -media user participation-is expected, attracted by the collaborative and entertainment dimension that such demonstrations can cause.

\section{Discussion and conclusions}

It is realized that there is an effective presence of the media which permeates into the everyday life of individuals, determining logical and interactional processes; that is to say: mediatization. In the case of brand publicity, a vast menu of strategies for the dissemination of opportunities are to be found. These are not consolidated and are changing the traditional forms of advertising planning.

Now it is necessary to identify the uncontrollable creative strategies which are designed to circulate. To put the brand into circulation on the Web is the best result that can be achieved through these strategies. These aspects indicate (1) greater consumer participation, as a user of the social networks; and (2) a market formula which is based on the use of the spontaneous service of the consumer-collaborator or prosumer.

On the other hand, the strategy also points to the growing power of the consumer who registers and gives voice to the thoughts of those media spaces and who can also criticize and question brands, as is highlighted in the example of "United breaks guitar" which arose out of a claim of a country singer who put a video on YouTube because an airline had broken his Mark Taylor-brand guitar during a flight.

The context of the new media seems to reconfigure power relations, providing a game of more balanced relations between producers and consumers.

Advertising is not limited to traditional formats already known, and it expands its borders to new spaces. Today, the advertising system serves as a way of communication for the brand by using "tags" in search systems such as Google. It is disguised in institutional and synthetic communication strategies of Twitter and also allows for the formation of opinion: a critical opinion which, with a new way of managing, gives expression to the relationship between the general public and communities of followers, as happens on Facebook and in blogs. Advertising also seems to be present in some new kinds of possibilities, those of the two-step-flow theories and as gatekeepers for formation and dissemination of opinions on networks.

On the Web there are many opportunities for freedom of expression which, throughout the world, allow for the aesthetic production of voice and image, and this production is no longer restricted to verbal communication, or by media type. Today innumerable illustrious unknown authors circulate products (audiovisual products and parodies on YouTube), and images as a way of networking through exchanges of photographic productions like Instagram and Flicker; all of which demonstrates this plethora of free expression which has been spoken about.

All these sites are spaces where brands can be announced or advertised, can be screened, so as to cultivate sensory bonds. Hence, it is believed that there is a need to develop ways to understand the qualitative nature of these sensory bonds.

In this way, the tradition of Latin-American thought can, through qualitative studies, concern itself with supplying theoretical solutions, aimed at the creation of meaning, and linkages between brands and consumers, as is the intent of this document. In doing so, a different position is assumed to that of the Anglo-Saxon, especially North American, which is more focused on the study of the effects. As a counterpoint to the latter, a closer look has been taken here at the socio-cultural aspects.
Advertising is not limited to traditional formats already known, and it expands its borders to new spaces. Today, the advertising system serves as a way of communication for the brand by using "tags" in search systems such as Google 


\section{References}

Amorós-Pons, Anna; Comesaña-Comesaña, Patricia (2016). “Cartoons, publicidad y transmedialidad". Cuadernos.info, n. 39, pp. 165-180.

https://doi.org/10.7764/cdi.39.752

Baudrillard, Jean (1969). El sistema de los objetos. Madrid: Siglo XXI. ISBN: 9682303478

Bauman, Zygmunt (2001). Modernidade líquida. Rio de Janeiro: Zahar. ISBN: 8537807729

Benavides-Delgado, Juan (2005). “Nuevas propuestas para el análisis del lenguaje en los medios”. Questiones publicitarias, v. 1, n. 10, pp. 13-33.

https://doi.org/10.5565/rev/qp.154

Braga, Adriana (2006a). "Técnica etnográfica aplicada à comunicação online: uma discussão metodológica". UN/revista, v. 1, n. 3, pp. 1-11.

Braga, José-Luiz (2006b). "Sobre 'mediatização' como processo interacional de referência”. En: Anais XV Encontro Nacional da Compós, Unesp-Bauru, 6-9 de junho.

https://goo.gl/YeD7U8

Caro-Almala, Antonio (2007). "La publicidad como núcleo de un imaginario globalizado". In: Hellín-Ortuño, Pedro A. (ed.). El discurso publicitario contemporáneo. Su relación con lo social. Murcia: Diego Marín, pp. 79-97. ISBN: 978 84 84256137

Casaqui, Vander (2011). "Por uma teoria da publicização: transformações no processo publicitário". Significação. Revista de cultura audiovisual, v. 38, n. 36, pp. 131-151.

https://doi.org/10.11606/issn.2316-7114.sig.2011.70935

Checa-Montúfar, Fernando (2011). “De la 'recepción' al 'consumo': una necesaria reflexión conceptual”. In: Jacks, Nilda (org.), Análisis de recepción en America Latina: un recuento histórico con perspectivas al futuro, pp. 13-17. Quito: Ciespal. ISBN: 9789978550892

https://biblio.flacsoandes.edu.ec/shared/biblio_view.php?bibid=127940\&tab=opac

Codina, Lluís (2018). Revisiones bibliográficas sistematizadas: procedimientos generales y framework para ciencias humanas y sociales. Barcelona: Universitat Pompeu Fabra, Departamento de Comunicación, Máster Universitario en Comunicación Social.

http://hdl.handle.net/10230/34497

Couldry, Nick; Hepp, Andreas (2013). “Conceptualizing mediatization: contexts, traditions, arguments". Communication theory, v. 23, n. 3, pp. 191-102.

https://doi.org/10.1111/comt.12019

Di-Nallo, Egeria (1999). Meeting points. Soluções de marketing para uma sociedade complexa. São Paulo: Cobra. ISBN: 8585536209

Fausto-Neto, Antonio (2010). "As bordas da circulação...". Alceu, v. 10, n. 20, pp. 55-69.

http://revistaalceu-acervo.com.puc-rio.br/cgi/cgilua.exe/sys/start.htm?infoid=367\&sid=32

Garrido-Pintado, Pablo; Estupiñán-Estupiñán, Óscar (2016). "Analysis of character construction in transmedia advertising narrative". Prisma social, n. 17, pp. 140-161.

http://revistaprismasocial.es/article/view/1280

Giddens, Anthony (2002). Modernidade e identidade. Rio de Janeiro: Zahar. ISBN: 9788571106697

Hellín-Ortuño, Pedro A. (2007). Publicidad y valores postmodernos. Madrid: Siranda. ISBN: 9788498216936

Ibrus, Indrek; Scolari, Carlos A. (2012). Crossmedia innovations. Texts, markets, institutions. Frankfurt: Peter Lang. ISBN: 9783631622285

Jenkins, Henry (2008). Cultura da convergência. São Paulo: Aleph. ISBN: 9788576570844

Kotler, Philip; Kartajaya, Hermawan; Setiawan, Iwan (2011). Marketing 3.0. As forças que estão definindo o novo marketing centrado no ser humano. Rio de Janeiro: Campus. ISBN: 8535238697

Lacalle, Charo (2010). As novas narrativas da ficção televisiva e a internet. Matrizes, v. 3, n. 2, pp. 79-102.

https://doi.org/10.11606/issn.1982-8160.v3i2p79-102

Lévy, Pierre (2011). La sphère sémantique. Tome 1, Computation, cognition, économie de l'information. Paris: Hermès. ISBN: 9782746225060 
Lipovetsky, Gilles (2007). A felicidade paradoxal. Ensaio sobre a sociedade de hiperconsumo. São Paulo: Cia. Das Letras. ISBN: 853591093X

Livingstone, Sonia (2011). Media literacy: Ambitions, policies and measures. Brussels: COST. ISBN: 9782960115727 http://eprints.Ise.ac.uk/56879

Lopes, Maria-Immacolata-Vasallo (2009). Fiç̧ão televisiva no Brasil: temas e perspectivas. São Paulo: Globo Universidade. ISBN: 8525047961

Lopes, Maria-Immacolata-Vasallo (2011). Ficção televisiva transmidiática no Brasil: plataformas, convergência, comunidades virtuais. Porto Alegre: Sulina. ISBN: 852050633X

Lopes, Maria-Immacolata-Vasallo (org.) (2013). Estratégias de transmidiação na ficção televisiva Brasileira. Porto Alegre: Sulina. ISBN: 8520504523

http://especial.globouniversidade.redeglobo.globo.com/livros/ficcao_televisiva.pdf

McCracken, Grant (2003). Cultura e consumo. Novas abordagens ao caráter simbólico dos bens e das atividades de consumo. Rio de Janeiro: Mauad. ISBN: 9788574787855

Ribeiro, José-da-Silva; Bairon, Sérgio (orgs). (2007). Antropologia visual e hipermedia. Porto: Afrontamento. ISBN: 978 9723608694

Rocha, Everardo (2006). Representações do consumo. Estudos sobre a narrativa publicitária. Rio de Janeiro: Mauad. ISBN: 9788574782010

Scolari, Carlos A. (2009). "Transmedia storytelling: Implicit consumers, narrative worlds, and branding in contemporary media production". International journal of communication, v. 3, pp. 586-606.

https://ijoc.org/index.php/ijoc/article/view/477/336

Semprini, Andrea (2006). A marca pós-moderna. São Paulo: Estação das Letras. ISBN: 9788560166022

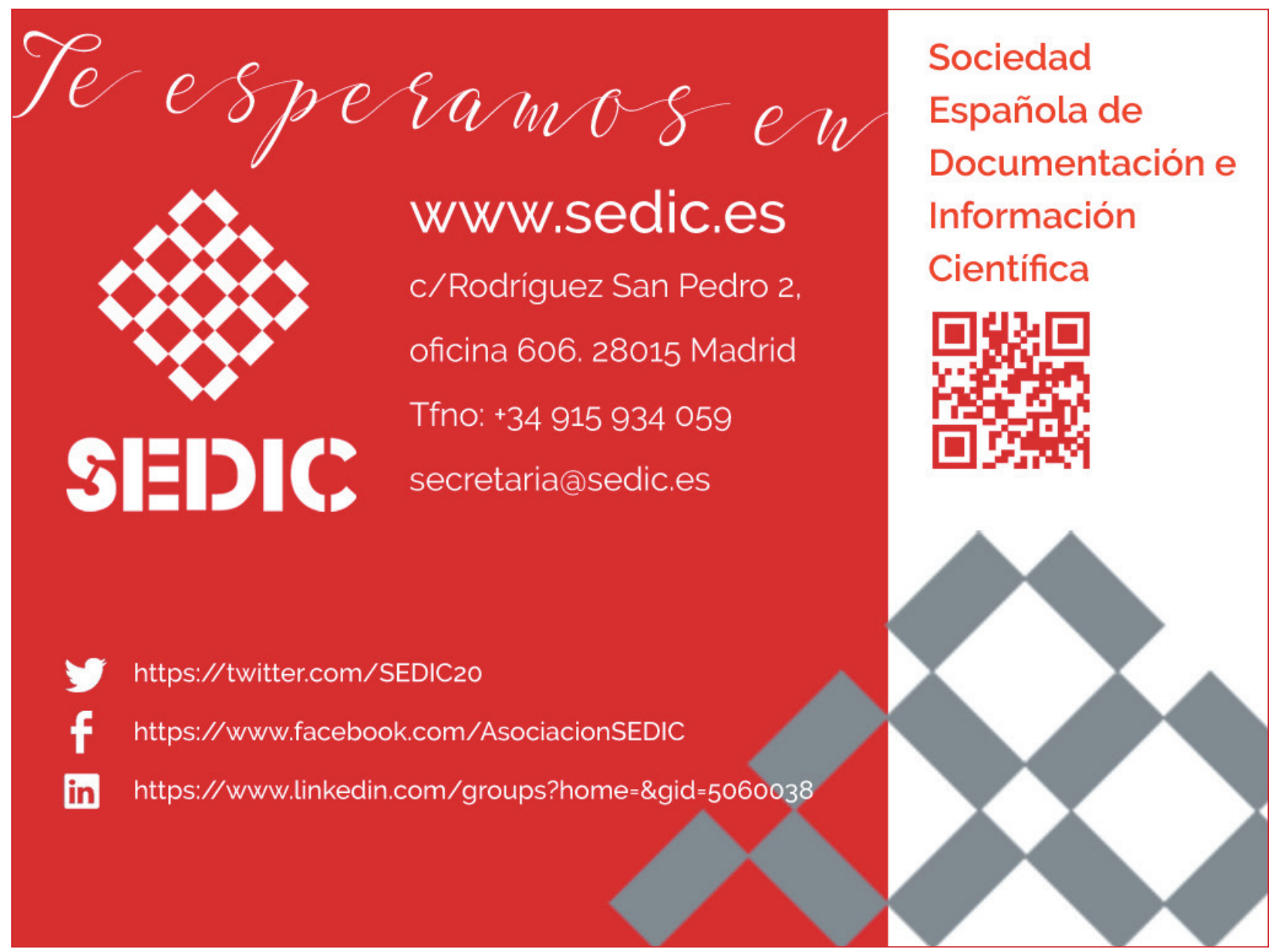

